\title{
Voltammetric Determination of Nimesulide Using Multiwalled Carbon Nanotubes Modified Carbon Paste Electrode
}

\author{
Çok Duvarlı Karbon Nanotüp ile Modifiye Edilmiș Karbon Pasta Elektrot Kullanılarak \\ Nimesulidin Voltametrik Miktar Tayini
}

Fatma AĞIN*, Vildan SERDAROĞLU

Karadeniz Technical University, Faculty of Pharmacy, Department of Analytical Chemistry, Trabzon, TURKEY

\begin{abstract}
A multiwalled carbon nanotubes (MWCNTs) modified carbon paste electrode (CPE) was prepared for voltammetric determination of antiinflammatory drug nimesulide (NIM). The electro-oxidation of NIM was exhibited irreversible and diffusion controlled process with MWCNTs modified CPE. The linear response between peak current and concentration in the quantitative determination of NIM by differential pulse voltammetry in $0.1 \mathrm{M}$ phosphate buffer solution (PBS) at $\mathrm{pH} 5.0$ obtained in the range of the concentration from $6 \times 10^{-8}-1 \times 10^{-5} \mathrm{M}$ with limit of detection (LOD) $1.07 \times 10^{-9} \mathrm{M}$ and limit of quantification (LOQ) $3.24 \times 10^{-9} \mathrm{M}$. Differential pulse voltammetry was developed according to linear response of NIM with high selectivity, precision, accuracy using modified electrode was successfully applied to the determination of NIM in pharmaceuticals and human serum samples.
\end{abstract}

Key words: Carbon paste electrode, Determination, Multiwalled carbon nanotubes, Nimesulide, Voltammetry

öz

Antienflamatuvar ilaç etken maddesi nimesulidin (NIM) voltametrik miktar tayini için çok duvarlı karbon nanotüp ile modifiye edilmiş karbon pasta elektrot hazırlanmıştır. NIM'in çok duvarlı karbon nanotüp ile modifiye edilmiş karbon pasta elektrot ile elektro-oksidasyonu tersinmez ve difüzyon kontrollü bir özellik göstermiştir. NIM'in diferansiyel puls voltametrisi ile $0.1 \mathrm{M}$ fosfat tampon çözeltisinde pH 5.0 de miktar tayininde

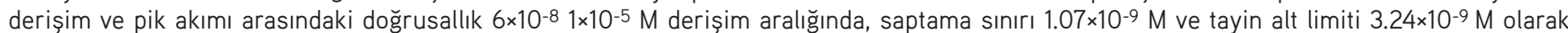
bulunmuştur. Çok duvarlı karbon nanotüp ile modifiye edilmiş karbon pasta elektrodu kullanarak NIM'nin doğrusal cevabına göre yüksek seçicilik, kesinlik, ve doğrulukla geliştirilen diferansiyal puls voltametrisi, NIM'nin farmasötik preparatlardan ve insan serum numunelerinden miktar tayinine başarılı bir şekilde uygulanmnıștır.

Anahtar kelimeler: Karbon pasta elektrot, Tayin, Çok duvarlı karbon nanotüp, Nimesulid, Voltametri

\section{INTRODUCTION}

Nimesulide, $\mathrm{N}$-(4-nitro-2 methanosulfonanilid) (Figure 1), is a new non-steroidal anti-inflammatory drug that is selective for cyclooxygenase-2 and effective in reducing the pain which is associated with rheumatoid arthritis and osteoarthirits (1). $\mathrm{pK}_{\mathrm{a}}$ value of NIM is 6.46 that is very important for gastric tolerability, and this avoids the back diffusion of the hydrogen ions that are liable for tissue damage. NIM is nearly completely biotransformed to 4-hydoxynimesulide in free and conjugated forms and it provides to promote to the anti-inflammatory activity of $\operatorname{NIM}(2,3)$.

There are several reports on the determination of NIM in the literature for example HPLC (high performance liquid chromatography) (4), with spectrophotometry UV (ultraviolet) (5,6), capillary electrophoresis (7). Most of this methods appear as time-consuming, expensive, complicated and lengthy procedures. Electrooxidation of NIM at gold electrode (8), electroreduction of NIM using glassy carbon electrode modified with $\mathrm{SiC}$ (silicon carbide) (9) and MWCNTs (multiwalled carbon nanotubes) modified glassy carbon electrode (10) have been reported in the literature. Electrochemical methods have certain advantages for example fast response, low cost and high sensitivity compare to other analytical methods $(11,12)$.

Carbon nanotubes (CNTs) can be used as electrode material for electrochemical and bioelectrochemical applications 
because of their unique characteristics and useful properties for example high chemical stability, conductivity, aspect ratio, and extremely high mechanical strength and modules (1316). CNTs are largely used as working electrode modification material for drug analysis due to they have the capability for promoting electron transfer reactions and developing sensitivity in electrochemistry (17).

In this study, a sensitive MWCNTs modified CPE was prepared for electroanalytical determination and it used to investigate electro-oxidative behavior of NIM with cyclic and differential pulse voltammetry. The prepared MWCNTs modified CPE was exhibited rapid response, high selectivity, sensitivity, low detection limit, and good reproducibility and successfully used electroanalytical determination of NIM.

\section{EXPERIMENTAL}

\section{Instrumentation}

Voltammetric measurements were carried out with a computer-controlled Autolab Pgstat128n potentiostat/ galvanostat with Nova 10.0 software (Metrohm-Autolab, The Netherlands). A three-electrode electrochemical cell analyzer contains a carbon paste electrode with modification<smiles>COS(=O)(=O)c1ccc([N+](=O)[O-])cc1Oc1ccccc1</smiles>

Figure 1. Molecular structure of nimesulide

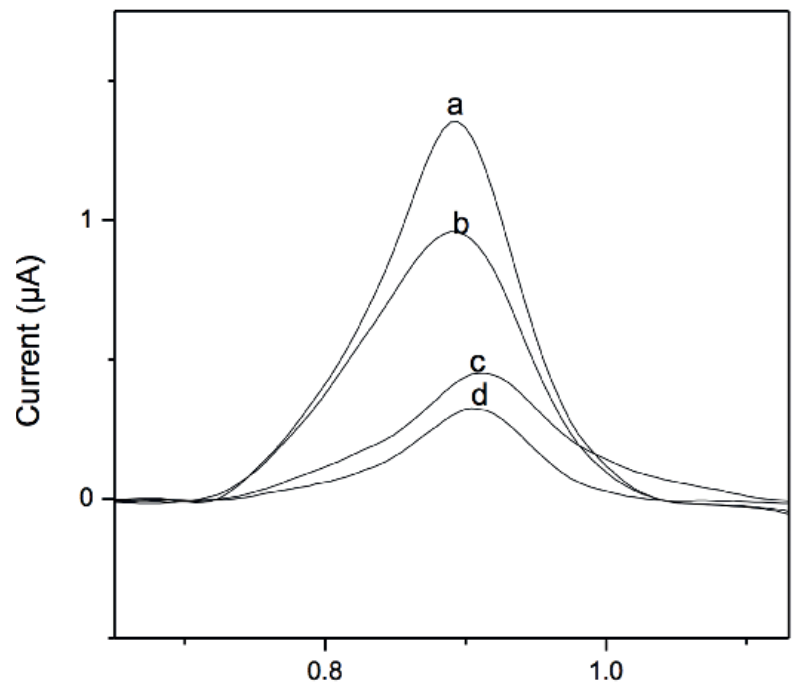

Figure 2. Differential pulse voltammograms $10 \mu \mathrm{M}$ of NIM in $0.04 \mathrm{M}$ Britton-Robinson buffer at pH 7.0, (a) $0.2 \%, 2.5 \mu \mathrm{L}$; (b) $0.5 \%, 1 \mu \mathrm{L}$; (c) $0.5 \%, 3 \mu \mathrm{L}$, (d) $0.2 \%, 5 \mu \mathrm{L}$ of MWCNTs
MWCNTs as working electrode, a platinum wire as the counter electrode and $\mathrm{Ag} / \mathrm{AgCl}$ electrode as the reference electrode. The $\mathrm{pH}$ measurements were carried out using model Hanna HI2211 pH meter (Romania) with an accuracy of $\pm 0.05 \mathrm{pH}$ at room temperature.

\section{Reagents}

Nimesulide and its pharmaceutical dosage form tablet (100 mg per tablet) were supplied by Sanovel-Turkey. They were used without further purification. Stock solutions of NIM (1×10-3 $\mathrm{M})$ were prepared in methanol and stored at $+4^{\circ} \mathrm{C}$ away from light. NIM working solutions for voltammetric investigation were prepared by the direct dilution of the stock solution with selected supporting electrolyte containing a constant amount of methanol (20\% (v/v)). Graphite powder ( $d=2.2 \mathrm{~g} / \mathrm{mL}$, Merck, Germany) and paraffin oil ( $d=0.84 \mathrm{~g} / \mathrm{mL}$, Aldrich, U.S.A) as the binding agent were used for preparing the pastes. MWCNTs was purchased from NanoLab. U.S.A, with purity 95\%, 30 \pm 10 $\mathrm{nm}$ diameter, and 1-5 $\mu \mathrm{m}$ lengths.

Phosphate buffer solutions (PBS) (0.1 M) were prepared from phosphoric acid (Merck, Germany) for pH 4.0 and disodium hydrogen phosphate (Aldrich, U.S.A.), sodium dihydrogen phosphate (Merck, Germany) for pH 5.0-8.0. BrittonRobinson (BR) buffer solutions (0.04 M) were prepared at $\mathrm{pH}$ 3.0-9.0 from 0.04 M phosphoric acid (Merck, Germany), 0.04 $\mathrm{M}$ boric acid (Aldrich, U.S.A.) and $0.04 \mathrm{M}$ acetic acid (Merck, Germany). Acetate (AT) buffer solutions (1 M) at pH 3.5, 4.5 were prepared from $1 \mathrm{M}$ acetic acid (Merck, Germany). $\mathrm{pH}$ was adjusted with $5 \mathrm{M}$ sodium hydroxide (Aldrich, U.S.A.) solution.

Sartorius Arium proUV nanopure water (resistivity $\geq 18 \mathrm{M} \Omega$ $\mathrm{cm}$ ), and analytical reagents were used for the preparation

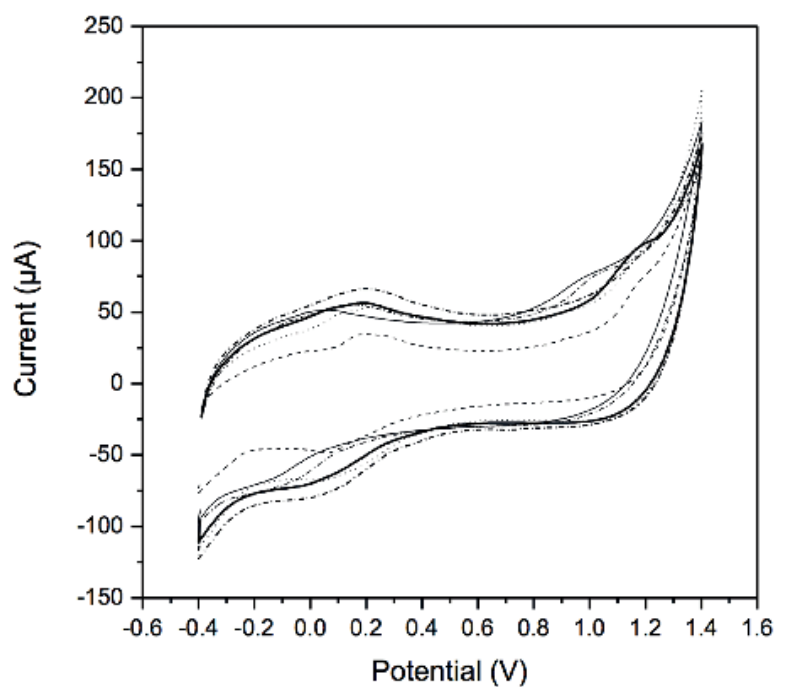

Figure 3. Cyclic voltammograms of NIM in $1 \mathrm{M}$ acetate buffer at $\mathrm{pH} 3.5$ (----), $0.1 \mathrm{M}$ phosphate buffer at pH 4.0 (.....), pH 5.0 (-), $0.04 \mathrm{M}$ BrittonRobinson buffer pH 7.0 (---.-), pH 9.0 (-) with MWCNTs modified CPE. Short dash dot line $0.1 \mathrm{M}$ phosphate buffer at pH 5.0; NIM concentration: $100 \mu \mathrm{M}$; scan rate $100 \mathrm{mV} / \mathrm{s}$ 
of solutions. All of the experiments were performed at room temperature $\left(25 \pm 1^{\circ} \mathrm{C}\right)$.

Preparation of bare and MWCNTs modified carbon paste electrodes

The ratio of graphite powder and paraffin oil to binder were optimized for NIM, and then the carbon paste electrode was prepared homogeneous paste by thoroughly hand-mixing the from optimized graphite powder and paraffin oil in the ratio of $75: 25(\mathrm{w} / \mathrm{w})$. A portion of the homogeneous paste was packed into the cave of the teflon tube. A copper wire inserted into the carbon paste provided the electrical contact. When necessary, a new surface was obtained by pushing an excess of the paste out of the tube and polishing with a weighing paper.

The MWCNTs were dispersed in DMF with loading $0.2 \%(\mathrm{w} / \mathrm{v})$ and sonicated for $4 \mathrm{~h}$ to obtain a homogeneous mixture. A selected $2.5 \mu \mathrm{L}$ of the dispersion was dropped directly on the surface of CPE. The resulting modified electrode was named as MWCNTs modified CPE. The MWCNTs modified CPE electrode dried for overnight at room temperature.

\section{Pharmaceutical assay}

Ten tablets (each tablet contains $100 \mathrm{mg}$ NIM) were first weighed and then finely powdered. The required amount of powder equivalent to $10^{-3} \mathrm{M}$ of NIM was diluted to $100 \mathrm{~mL}$ with methanol and sonicated for $15 \mathrm{~min}$. The analyzed solutions were prepared by taking suitable aliquots of the clear supernatant liquor and diluting with the selected supporting electrolyte NIM working solutions for voltammetric investigation were prepared by the direct dilution of the stock solution with selected supporting electrolyte containing a constant amount of methanol ( $20 \% \mathrm{v} / \mathrm{v})$.

\section{Analysis of serum}

Drug-free human serum samples were obtained from healthy people and stored frozen in the dark until assay. An aliquot volume of serum sample was fortified with NIM dissolved in methanol to achieve final concentration of $1 \times 10^{-3} \mathrm{M}$ and treated with acetonitrile to removing serum proteins effectively. Blank and stock solution of NIM were transported to ultrasonic bath and agitated for $15 \mathrm{~min}$ and subsequently centrifuged for 15
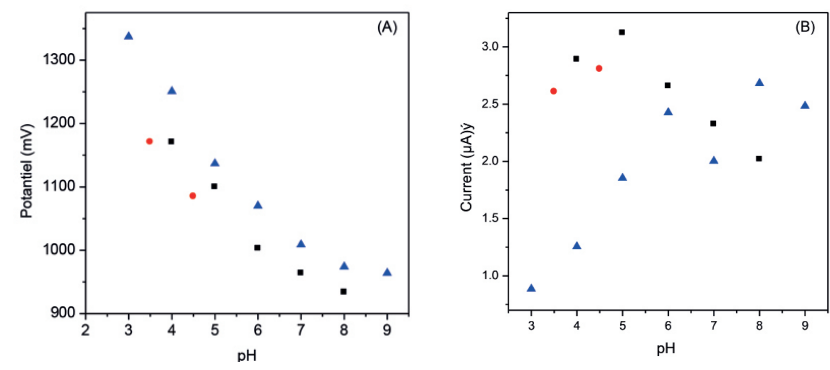

Figure 4. Plots of peak potential, $\left(E_{\mathrm{p}}\right)$, versus $\mathrm{pH}(\mathrm{A})$ and peak current $(/ \mathrm{p})$, versus $\mathrm{pH}(\mathrm{B})$ from cyclic voltammetry voltammograms of $100 \mu \mathrm{M}$ of NIM with MWCNTs modified CPE. Squares indicate $0.1 \mathrm{M}$ phosphate buffer solution, tringle $0.04 \mathrm{M}$ Britton-Robinson buffer solution and circles $1 \mathrm{M}$ acetate buffer solution min at $5000 \mathrm{rpm}$ to separate serum protein residues and supernatant. Appropriate volumes of this supernatant were taken carefully and transferred into the volumetric flask and diluted up to the required volume with the selected supporting electrolyte containing a constant amount of methanol $(20 \%$ $\mathrm{v} / \mathrm{v})$.

\section{Validation of the analytical methods}

The ruggedness, precision, and accuracy of the studied methods, were checked by assaying five replicate samples on the same day and on different days over a week. Relative standard deviations (\%) were also calculated to check the ruggedness and precision of the method. The accuracy of the methods was expressed as bias $(\%)(18,19)$. Each of the solutions was freshly prepared just before the experiments and protected from the light. All of the measurements were carried out at room temperature $\left(25 \pm 1^{\circ} \mathrm{C}\right)$. The calibration equation for differential pulse voltammetry method was constructed by plotting the peak current against NIM concentration.

\section{RESULTS AND DISCUSSION}

Effect of volume variations on the peak current was investigated at two different concentrations of MWCNTs suspension $(0.2 \%$ and $0.5 \%$ in DMF) to optimize MWCNTs volume for determination of NIM (Figure 2). The suspension amounts of $2.5 \mu \mathrm{L}$ and $5 \mu \mathrm{L}$ for $0.2 \%$ of MWCNTs, $1 \mu \mathrm{L}$ and 3 $\mu \mathrm{L}$ for $0.5 \%$ of MWCNTs suspension were studied for $10 \mu \mathrm{M}$ NIM with CV and DPV. As shown in Figure 1, the peak current reaches its maximum value when the suspension amount is $2.5 \mu \mathrm{L}$ for $0.2 \%$ MWCNTs. So, $2.5 \mu \mathrm{L}$ was chosen as the optimized amount for $0.2 \%$ MWCNTs suspension.

The electro-oxidation behavior of NIM on MWCNTs modified CPE was studied by $\mathrm{CV}$ at a scan rate of $100 \mathrm{mV} / \mathrm{s}$ between

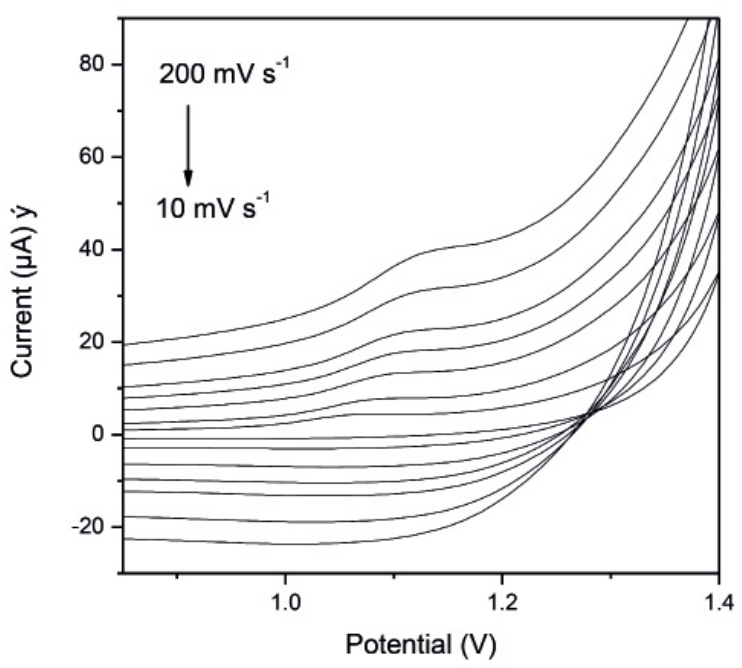

Figure 5. Cyclic voltammograms of $100 \mu \mathrm{M}$ of NIM in $0.1 \mathrm{M}$ phosphate buffer solution at pH 5.0 at scan rates of 10, 25, 50,75, 100, 150 and $200 \mathrm{mV} / \mathrm{s}$ with MWCNTs modified carbon paste electrode 
$\mathrm{pH} 3.0$ and 9.0 in different buffer solutions. The cyclic voltammetric measurements (Figure 3) performed for $100 \mu \mathrm{M}$ NIM solution exhibit that NIM has irreversible electrochemical oxidation behavior on MWCNTs modified CPE.

Effect of $\mathrm{pH}$ on the anodic peak current and peak potential of $100 \mu \mathrm{M}$ NIM were analyzed with cyclic and differential pulse voltammetry in different buffer solutions between $\mathrm{pH} 3.0$ and 9.0 using MWCNTs modified CPE electrode. Due to detection responses for $\mathrm{CV}$ and DPV are similar, only cyclic voltammetry

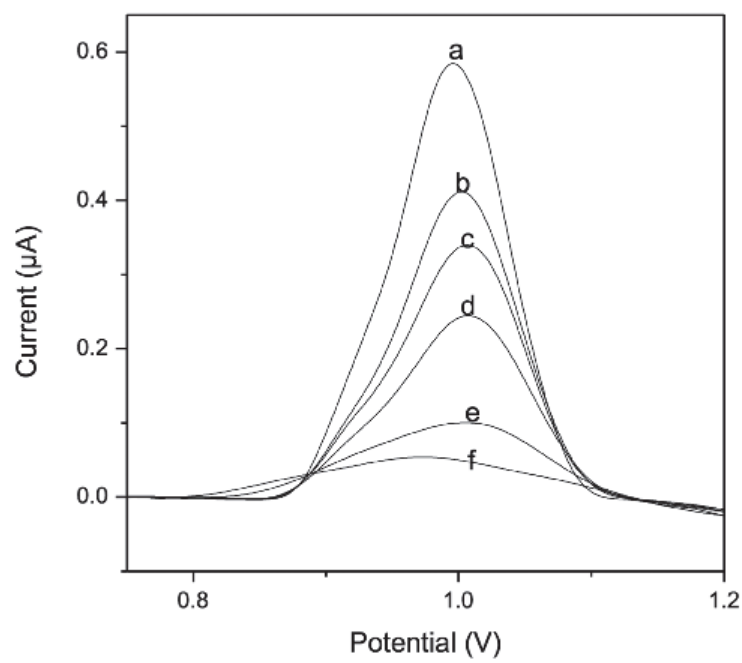

Figure 6. Differential pulse voltammograms (a) 10, (b) 8, (c) 6, (d) 4, (e) 1, (f) $0.4 \mu \mathrm{M}$ of NIM solution in $0.1 \mathrm{M}$ phosphate buffer solution at $\mathrm{pH} 5.0$ with MWCNTs modified carbon paste electrode

Table 1. Validation data of calibration lines for the quantitative determination of NIM by DPV for MWCNTs modified carbon paste electrode in 0.1 M PBS at pH 5.0 and serum samples

\begin{tabular}{|c|c|c|}
\hline & \multicolumn{2}{|c|}{$\begin{array}{l}\text { MWCNTs modified carbon } \\
\text { paste electrode }\end{array}$} \\
\hline & $\begin{array}{l}\text { Supporting } \\
\text { electrolyte }\end{array}$ & $\begin{array}{l}\text { Spiked } \\
\text { serum }\end{array}$ \\
\hline & DPV & DPV \\
\hline Peak potential (V) & 1.006 & 1.012 \\
\hline Linearity range $(\mu \mathrm{M})$ & $0.06-10$ & $0.4-40$ \\
\hline Slope $(\mu \mathrm{A} / \mu \mathrm{M}-1)$ & 89055 & 29531 \\
\hline Intercept $(\mu \mathrm{A})$ & +0.1008 & +0.0672 \\
\hline Correlation coefficient & 0.9922 & 0.9977 \\
\hline Limit of detection $(\mu \mathrm{M})$ & 0.00107 & 0.0363 \\
\hline Limit of quantification $(\mu \mathrm{M})$ & 0.00324 & 0.1101 \\
\hline Repeatability of peak current (R.S.D.\%) & 0.581 & 0.424 \\
\hline $\begin{array}{l}\text { Repeatability of peak potential } \\
\text { (Relative standard deviation \%) }\end{array}$ & 0.418 & 0.255 \\
\hline $\begin{array}{l}\text { Reproducibility of peak current } \\
\text { (Relative standard deviation \%) }\end{array}$ & 0.808 & 0.669 \\
\hline $\begin{array}{l}\text { Reproducibility of peak potential } \\
\text { (Relative standard deviation \%) }\end{array}$ & 0.961 & 0.566 \\
\hline
\end{tabular}

responses of NIM were exhibited in Figure 4. As shown in Figure 4, NIM show irreversible anodic peak in the studied all $\mathrm{pH}$ values. The peak potential in the oxidation process of NIM shifted to less positive potentials (Figure 4A) with increasing $\mathrm{pH}$. Anodic peak of NIM exhibited a $\mathrm{pH}$ dependent behavior between $\mathrm{pH} 3.0$ and 7.0 with linear relationship (equation 1).

$E_{\mathrm{p}}(\mathrm{mV})=1298-64.1 \mathrm{pH} ; \mathrm{r}=0.992$ (between $\mathrm{pH} 3.0$ and 7.0 ) (equation 1)

The observed $\mathrm{pH}$ dependence in the electro-oxidation behavior of NIM indicated that the methylsulfonamide group (electroactive group) corresponding to the NIM main oxidation peak was in acid-base equilibrium with $\mathrm{pK}_{\mathrm{a}}$ of about 7.0. The breaking point of the curve was close to the $\mathrm{pK}_{a}$ value of NIM, at about 6.56 (20). The obtained slope value for plot of peak potential versus $\mathrm{pH}$ was close to theoretical value of $59 \mathrm{mV} / \mathrm{pH}$ in the Nerst equation. This corresponds to the oxidation process of NIM involves equal number of electrons and protons $(21,22)$. The peak potential of NIM nearly was $\mathrm{pH}$ independent (Figures 4A), above $\mathrm{pH}$ 7.0. This attributed because of a change in the protonation-deprotonation process of the methylsulfonamide and the oxidation potential of NIM remains $\mathrm{pH}$ independent and before the electron transfer rate-determining step there are no proton transfer steps. The conjugate base must be formed by rapid dissociation of the protonated form at $\mathrm{pH}\left\langle\mathrm{pK}_{\mathrm{a}}\right.$. The plot of peak current versus $\mathrm{pH}$ is shown in Figure 4B. The maximum peak current and well peak shape of oxidation NIM were obtained in 0.1 M PBS at $\mathrm{pH}$ 5.0. Thus, electroanalytical determination of NIM and further studies were studied in 0.1 M PBS at pH 5.0.

The effect of scan rate over the range of $10.0-200.0 \mathrm{mV} / \mathrm{s}$ on the peak potential and peak current was studied by $\mathrm{CV}$ in PBS at $\mathrm{pH}$ 5.0. The peak potential of $100 \mu \mathrm{M}$ NIM in 0.1 $\mathrm{M}$ PBS at pH 5.0 is moved to the anodic direction with the scan rate increasing (Figure 5). The plot of logarithm of peak

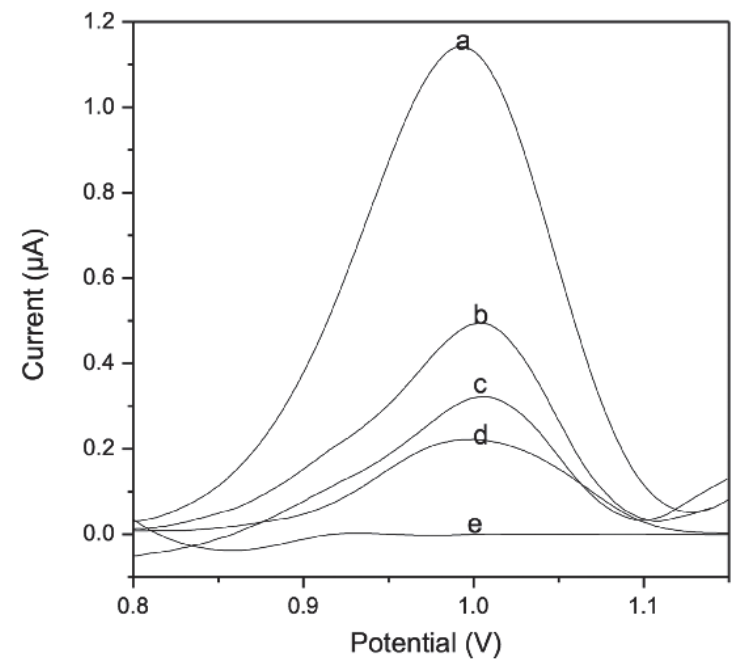

Figure 7. Differential pulse voltammograms (a) 40, (b) 20, (c) 8 , (d) $6 \mu \mathrm{M}$ of NIM solution ( $f$ ) blank solution in spiked serum $0.1 \mathrm{M}$ phosphate buffer solution at pH 5.0 with MWCNTs modified carbon paste electrode 
current versus the logarithm of scan rate showed a linearity with a slope value of 0.341 (equation 2) and the plot of peak current versus square root scan rate exhibited a straight line with a slope value of 0.166 (equation 3 ). These values of the slopes were found to be close to the theoretical value of 0.5 . This contributes that the electro-oxidation process of NIM is diffusion controlled process on the MWCNTs modified CPE (23). Related equations are noted below:

$\log I_{p}=0.341 \log v-0.339 r=0.991 n=8$ (equation 2 )

$I_{\mathrm{p}}=0.166 v^{1 / 2}+0.519 \mathrm{r}=0.991 \mathrm{n}=8$ (equation 3 )

Validation of the analytical procedure

Voltammetric studies for determination of the NIM were carried out by DPV. DPV was selected due to the peaks are sharper and better determined at lower concentration of NIM than the peaks derived by CV. The anodic peak current increased linearly with increasing concentration of NIM in the DP voltammograms, as shown in Figure 6. The MWCNTs modified CPE showed linearity in the range from 0.06 and 10 $\mu \mathrm{M}$ of NIM for DPV.

The related validation parameters for DPV and characteristics of the calibration equation are reported in Table 1 . The developed DPV was validated according to standard validation procedures $(24,25)$. Limit of detection and limit of quantification were calculated according to $3 \mathrm{~s} / \mathrm{m}$ and $10 \mathrm{~s} / \mathrm{m}$, respectively, by using the standard deviation of the anodic peak response (s) and the slope value of the calibration curve (m) (26). The limit of detection value that was obtained in this study was the lowest value than the reported value in the literature for the electroanalytical determination of NIM.

We have investigated repeatability, reproducibility, precision, recovery, bias\%, and selectivity for validation NIM with MWCNTs modified CPE. All validation results for NIM with MWCNTs modified CPE were repetitive, selective, reproducibility measurements, as shown in Table 1 . The validation results demonstrate good precision, accuracy, repeatability and reproducibility (Table 1 ).

Table 2. The results for the determination of NIM from tablet dosage forms and recovery experiments in $0.1 \mathrm{M}$ PBS buffer at pH 5.0 by DPV for MWCNTs modified carbon paste electrode

\begin{tabular}{ll} 
& Tablet $(\mathrm{mg})$ \\
\hline Labeled claim (mg) & DPV \\
\hline Amount found (mg)* & 100 \\
\hline Relative standard deviation \% & 100.41 \\
\hline Bias \% & 0.278 \\
\hline Added (mg) & +0.406 \\
\hline Found (mg)* & 33.3 \\
\hline Average recovered (\%) & 34.16 \\
\hline Relative standard deviation \% of recovery & 100.64 \\
\hline Bias \% & 0.817 \\
\hline
\end{tabular}

\section{Determination of NIM in pharmaceutical dosage forms}

The MWCNTs modified CPE was applied for the determination of NIM in Nimes ${ }^{\circledR}$ tablet dosage form. Each NIM tablet in pharmaceutical dosage form contains $100 \mathrm{mg}$ NIM and inactive ingredients. The developed DPV was carried out to direct determination of NIM in pharmaceutical dosage form, using the related calibration straight line. Pretreatment such as evaporation, extraction was not required for tablet dosage form. The results obtained from the tablet dosage form are listed in Table 2. The proposed method could be successfully applied for NIM assay in tablet dosage form without any interference.

\section{Determination of NIM in spiked human serum samples}

The differential pulse voltammetry optimized was successfully carried out to the voltammetric determination of NIM in protein-free spiked human serum samples. Acetonitrile was used as a serum precipitating agent. No evaporation or extraction other than centrifugal protein separation at 5000 rpm was required before analyse for the drug. The calibration equation parameters and validation parameters were shown in Table 1. Obtained recovery results of human serum samples were given in Table 3.

Differential pulse voltammograms of 40 and $6 \mu \mathrm{M}$ of NIM obtained serum spiked were exhibited in Figure 7. As shown in Figure 7, no oxidation or noise peaks were present in

Table 3. Results of obtained for NIM determination from spiked serum

\begin{tabular}{ll} 
& DPV \\
\hline Added concentration $(\mu \mathrm{M})$ & 8.00 \\
\hline Obtained concentration $(\mu \mathrm{M})$ & 8.02 \\
\hline Number of experiments & 5 \\
\hline Average recovered $(\%)$ & 99.83 \\
\hline Relative standard deviation \% of recovery & 0.692 \\
\hline Bias \% & +0.25 \\
\hline
\end{tabular}

Table 4. Electrochemical detection of NIM at different modified electrodes

\begin{tabular}{|c|c|c|c|c|}
\hline Electrode & Method & $\begin{array}{l}\text { Linear range } \\
(\mu \mathrm{M})\end{array}$ & $\begin{array}{l}\text { Limit of } \\
\text { detection }(\mu \mathrm{M})\end{array}$ & Reference \\
\hline $\begin{array}{l}\text { Glassy carbon elec- } \\
\text { trode modified by } \\
\text { cysteic acid/CNTs }\end{array}$ & DPV & $0.1-10$ & 0.05 & 27 \\
\hline $\begin{array}{l}\text { Barium doped zinc } \\
\text { oxide nanoparticles } \\
\text { modified glassy } \\
\text { carbon electrode }\end{array}$ & DPV & $0.1-10$ & 0.0018 & 28 \\
\hline Gold electrode & DPV & $0.2-1.2$ & 0.0011 & 8 \\
\hline $\begin{array}{l}\text { Multiwalled carbon } \\
\text { nanotubes modified } \\
\text { carbon paste } \\
\text { electrode }\end{array}$ & DPV & $0.06-10$ & 0.00107 & This work \\
\hline
\end{tabular}


the potential range where the analytical peak was formed analytical peak and determination of NIM was successfully applied in human serum samples.

Serum samples was kept in $+4^{\circ} \mathrm{C}$ in darkness and the stability of serum samples was studied by five consecutive analyses of the serum samples over a period of, approximately, five hours. The peak currents and peak potentials of NIM was not shown significant changes between the first and last measurements.

As it is shown in Table 4, the MWCNTs modified CPE was compared to other modified electrode in the literature according to their linear range and limit of detection. The linear range for determination of NIM with MWCNTs modified CPE at this method are better than other electrochemical methods reported in literature $(27,28,8)$. When compared to limit of detection values for NIM with gold electrode (10), barium doped zinc oxide nanoparticles modified electrode glassy carbon electrode (28) and MWCNTs modified CPE (this study), this study has lowest limit of detection value.

\section{CONCLUSION}

Carbon paste electrode was modified with multiwalled carbon nanotubes and optimized for NIM. The prepared MWCNTs modified CPE was used electroanalytical determination of NIM CV and DPV. The MWCNTs modified CPE for electroanalytical determination of NIM using DPV was carried out highly selectively, simply and stably from pharmaceutical dosage forms and human serum samples. Additionally, simplicity of the electrode preparation is very practical. Thus, multiwall carbon nanotubes modified carbon paste electrode is a practical sensor and very useful for the voltammetric determination of NIM.

\section{REFERENCES}

1. Quattrini M, Paladin SA. A Double-Blind Study Comparing Nimesulide with Naproxen in the Treatment of Osteoarthritis of the Hip. Clin Drug Invest 10(3), 139-146, 1995.

2. Fallavena PRB, Schapoval EES. pKa determination of nimesulide in methanol-water mixtures by potentiometric titrations. Int $\mathrm{J}$ Pharm 158(1), 109-112, 1997.

3. Furlanetto S, Orlandini S, Aldini G, Gotti R, Dreassi E, Pinzauti S. Designing experiments to optimise and validate the adsorptive stripping voltammetric determination of nimesulide. Anal Chim 413(12), 229-239, 2000.

4. Patravale VB, Souza S, Narkar Y. HPTLC determination of nimesulide from pharmaceutical dosage forms. J Pharm Biomed Anal 25(3-4), 685-688, 2001.

5. Lakshimi CSR, Reddy MN. Spectrophotometric Estimation of Nimesulide and its Formulations. Microchim Acta 132(1), 1-6, 1999.

6. Chandran S, Saggar S, Priya KP, Saha RN. New Ultraviolet Spectrophotometric Method for the Estimation of Nimesulide Drug Dev Ind Pharm 26(2), 229-234, 2000.

7. Doğrukol-Ak D, Tuncel M, Aboul HY. A capillary zone electrophoretic method for the determination of nimesulide in pharmaceutical preparation and serum. J Sep Sci 24(9), 743-748, 2001.
8. Malode SJ, Nandibewoor ST. Electro-oxidation of nimesulide at gold electrode and its determination in pharmaceutical dosage form and human biological fluid. Asian Journal of Pharmaceutical and Clinical Research 6(3), 71-76, 2013.

9. Ghavami R, Navae A. Determination of nimesulide in human serum using a glassy carbon electrode modified with $\mathrm{SiC}$ nanoparticles. Microhimica Acta 176(3), 493-499.

10. Zhang J, Tan X, Zhao D, Tan S, Huang Z, Mi Y, Huang Z. Study of nimesulide and its determination using multiwalled carbon nanotubes modified glassy carbon electrodes. Electrochim Acta 55(3-4), 25222526, 2010

11. Yardım Y, Şentürk Z. Electrochemical Behavior of Folic Acid at A BoronDoped Diamond Electrode: Its Adsorptive Stripping Voltammetric Determination in Tablets. Turkish Journal of Pharmaceutical Sciences 11(1), 87-100,2014.

12. Ağın F, Karadaș N, Uslu B, Özkan SA. Voltammetric and RP-LC assay for the antidepressant drug mirtazapine: $A$ validated method for the pharmaceutical dosage form. Maced J Chem Chem En 32(1), 41-55, 2013.

13. Du D, Huang X, Cai J, Zhang A, Ding J, Chen S. An amperometric acetylthiocholine sensor based on immobilization of acetylcholinesterase on a multiwall carbon nanotube-cross-linked chitosan composite. Anal Bioanal Chem 387(3), 1059-1065, 2007.

14. Gooding JJ. Nanostructuring electrodes with carbon nanotubes: A review on electrochemistry and applications for sensing. Electrochim Acta 50(15), 3049-3060, 2005.

15. Male KB, Hrapovic S, Luong JHT. Electrochemically-assisted deposition of oxidases on platinum nanoparticle/multi-walled carbon nanotube-modified electrodes. Analyst 132(12), 1254-1261, 2007.

16. Du D, Huang X, Cai J, Zhang A. Comparison of pesticide sensitivity by electrochemical test based on acetylcholinesterase biosensor. Biosens Bioelectron 23(2), 285-289, 2007.

17. Dirk M, Guldi NM, Carbon nanotubes and related structures, Wiley, New York, 2010.

18. Bievre $P$, Günzler $H$, Validation in chemical measurements, Springer, New York, 2005.

19. Ermer J, Miller $\mathrm{H}$, Method validation in pharmaceutical analysis, WileyVCH, Veinheim, 2005

20. Singh S, Sharda N.; Mahajan, L. Spectrophotometric determination of pKa of nimesulide. International Journal of Pharmaceutics 176(2), 261264, 1999.

21. Álvarez-Lueje A, Vásquez P, Núlez-Vergara LJ, Squella JA. Voltammetric study of nimesulide and its differential pulse polarographic determination in pharmaceuticals. Electroanal 9(15), 1209-1213, 1997

22. Wang J. Electroanalytical techniques in clinical chemistry and laboratory medicine, VCH Publishers, New York, 1988.

23. Laviron E, Roullier L, Degrand CA. Multilayer model for the study of space distributed redox modified electrodes: Part II. Theory and application of linear potential sweep voltammetry for a simple reaction. J Electroanal Chem 112(1), 11-23, 1980.

24. Riley CM, Rosanske TW, Development and validation of analytical methods, Elsevier Science Ltd., New York, 1996.

25. Hart JP, Electroanalysis of biologically important compounds, Ellis Horwood Ltd., England, 1990. 
26. Berry IR and Harpaz D, Validation of active pharmaceutical ingredients 2nd ed., CRC Press, Washington, 2001.

27. Wang C, Shao X, Liu Q, Qu Q, Yang G, Hu X. Differential pulse voltammetric determination of nimesulide in pharmaceutical formulation and human serum at glassy carbon electrode modified by cysteic acid/CNTs based on electrochemical oxidation of L-cysteine. J Pharmaceut Biomed 42(2), 237-244, 2006.
28. Bukkitgar SD, Shetti NP, Kulkarni MR, Doddamani RM. Electrooxidation of nimesulide at $5 \%$ barium-doped zinc oxid nanoparticle modiDed glassy carbon electrode. J Electroanal Chem 762, 37-42, 2016.

Received : 07.04.2016

Accepted : 12.05.2016 